University of Nebraska - Lincoln

DigitalCommons@University of Nebraska - Lincoln

Faculty Publications: Agricultural Leadership, Education \& Communication Department
Agricultural Leadership, Education \& Communication Department

April 2005

\title{
Adoption of Riparian Forest Buffers on Private Lands in Nebraska, USA
}

\author{
Peter Skelton \\ University of Nebraska - Lincoln \\ Scott J. Josiah \\ University of Nebraska - Lincoln, sjosiah2@unl.edu \\ James W. King \\ University of Nebraska-Lincoln, jking1@unl.edu \\ James R. Brandle \\ University of Nebraska - Lincoln, jbrandle1@unl.edu \\ Glenn A. Helmers \\ University of Nebraska - Lincoln, ghelmers1@unl.edu \\ See next page for additional authors
}

Follow this and additional works at: https://digitalcommons.unl.edu/aglecfacpub

Part of the Other Public Affairs, Public Policy and Public Administration Commons

Skelton, Peter; Josiah, Scott J.; King, James W.; Brandle, James R.; Helmers, Glenn A.; and Francis, Charles, "Adoption of Riparian Forest Buffers on Private Lands in Nebraska, USA" (2005). Faculty Publications: Agricultural Leadership, Education \& Communication Department. 44.

https://digitalcommons.unl.edu/aglecfacpub/44

This Article is brought to you for free and open access by the Agricultural Leadership, Education \& Communication Department at DigitalCommons@University of Nebraska - Lincoln. It has been accepted for inclusion in Faculty Publications: Agricultural Leadership, Education \& Communication Department by an authorized administrator of DigitalCommons@University of Nebraska - Lincoln. 


\section{Authors}

Peter Skelton, Scott J. Josiah, James W. King, James R. Brandle, Glenn A. Helmers, and Charles Francis 


\title{
Adoption of Riparian Forest Buffers on Private Lands in Nebraska, USA
}

\author{
Peter Skelton and Scott. J. Josiah \\ School of Natural Resources \\ 107 Plant Industry \\ University of Nebraska \\ Lincoln, Nebraska 68583-0814, USA \\ James W. King \\ Agricultural Leadership, Education and Communication \\ 300 Agriculture Hall, University of Nebraska \\ Lincoln, Nebraska 68583-0709, USA \\ James R. Brandle \\ School of Natural Resources \\ 3B Plant Industry, University of Nebraska \\ Lincoln, Nebraska 68583-0814, USA \\ Glen A. Helmers \\ Agricultural Economics \\ 205B Filley Hall, University of Nebraska \\ Lincoln, Nebraska 68583-0922, USA \\ Charles A. Francis \\ Agronomy, 102B Kiesselbach \\ University of Nebraska \\ Lincoln, Nebraska 68583-0817, USA
}

Pesticide and nutrient runoff from agricultural fields is a socio-environmental problem in the Midwestern United States. Riparian forest buffers (RFBs) are a proven conservation practice that effectively manage this problem, though adoption rates are low. A mail survey was conducted to determine differences between adopter and nonadopter characteristics and attitudes with regard to the use of RFBs. Data were collected from 48 RFB adopters and 261 RFB nonadopters in two Nebraska watersheds. Inferential and multivariate statistics were used to identify differences between adopter status and producer status groups. About half $(50.8 \%)$ the respondents were nonproducers. Nonproducers are agricultural landowners not farming that make decisions about whether to install conservation practices on their land. Among the adopter respondents, non-farming agricultural landowners (nonproducers, $n=25)$ were as likely to adopt RFBs as producers $(n=23)$. Adopters were more informed about RFBs and willing to accept govermment payments. Receiving technical and financial assistance was a major key to 
adoption. The research has identified important opportunities for more effective and targeted RFB extension education programming.

Keywords: adopters, nonadopters, riparian forest buffer, watershed

\section{INTRODUCTION}

Surface water contamination from agricultural runoff contributes to declining water quality and ecosystem health in the United States (USDA 2003). Agricultural nonpoint sources of pollution have been linked to contamination of streams by runoff containing nutrients and pesticides in Nebraska (Nebraska Department of Environmental Quality 2002). The midwestern landscape is dominated by agroecosystems to which Riparian forest buffers (RFBs) can provide important environmental services relating to soil erosion and water quality.

Riparian forest buffers are a proven means to intercept and filter the negative effects of runoff from farm fields and agricultural operations. They remove large amounts of suspended sediment and associated nutrients from upland flow (Palone and Todd 1997, Schultz et al. 2004). Due to the frictional surfaces that slow runoff, sediment is deposited within the buffer and the transport of contaminants is slowed (Lowrance et al. 1988, 2002). Infiltration within the buffer is enhanced by the presence of woody plants (Colletti et al. 1995, Lee et al. 2003) contributing to the use and transformation of chemical inputs transported from upland areas. Riparian forest buffers substantially reduce runoff containing nitrogen and phosphorous (Osborne and Kovacic 1993, Palone and Todd 1997) and have the potential to assimilate and immobilise heavy metals and pesticides (Schultz et al. 2000).

To alleviate erosion and impaired surface water quality from agricultural sources, the United States government has provided generous financial incentives to landowners who install RFBs on their land. The incentives include compensation through land rental payments, sign-up incentives and maintenance dollars for the life of the contract. Due to these generous cost-share incentives, it is assumed that a lack of financial resources is not a barrier to adoption of RFBs because financial incentives for similar conservation practices have successfully facilitated the conversion of land from agricultural production to conservation.

Despite extensive research into the benefits of RFBs and governmental payment programs to install them, they have not been widely adopted. Soil erosion and runoff remain a problem. Limited attention has been paid to the factors affecting landowner decision to adopt RFBs. This paper discusses theoretical explanation of conservation adoption, followed by a general description of methods and procedures, and reports the findings from a study that identified factors affecting the use of RFBs in two eastern Nebraska watersheds. The goal of the study was to determine how respondent (e.g. adopters and nonadopters) characteristics affect adoption of RFBs and how this information could be used to enhance educational programs and increase the use of RFBs. 


\section{THEORETICAL EXPLANATIONS OF CONSERVATION PRACTICE ADOPTION}

Attempts to explain the adoption of conservation practices have focused on variables drawn from social-psychology, economics and farm structure theories. Surveying producers who have adopted or rejected a particular conservation practice as the study population is a data collection method common to many studies designed to explain adoption of conservation practices (Napier et al. 2000, Upadhyay et al. 2003). However, producers are not the only individuals who make conservation decisions. Fewer producers in the Midwest are farming more hectares and many of these producers rent land from non-producers. From 1997 to 2002, the total number of farms in Nebraska decreased by $9 \%$. In 2002, almost $42 \%$ of the total area in production was rented (USDA 2004). Findings by Constance et al. (1995) suggest that both nonproducer and absentee landowners are an increasingly important decision-making groups regarding conservation adoption.

Social-psychological models have been used extensively to explain adoption with an emphasis on explaining behaviour through individual perceptions (Van Es 1983) and the diffusion of innovations (Rogers 1983). Attitudinal variables used to explain adoption have included attitudes toward land-use problems and environmental problems. Landowner perceptions about a land-use problem are an important factor in determining the adoption of a conservation practice (Ervin and Ervin 1982). Several studies found that producers perceived surface water quality to be impaired by agricultural runoff at the regional and national level but that surface water quality impairment was only a slight problem at the local level (Napier et al. 1988, Lasley and Kettner 1990, Steiner 1990, Lichtenberg and Lessley 1992). Producers generally have a positive attitude toward environmental protection and minimising the negative effects of runoff (Norris and Batie 1987). However, adoption has been found to be affected adversely by negative attitudes towards government programs (Kraft et al. 1996). Diffusion variables used to explain adoption have included exposure to information from institutional and noninstitutional sources, and age of the respondent (Rogers 1983). Access to information and contact with change agents has been found to increase adoption rates (Nowak 1987, Kraft et al. 1996). Klapproth and Johnson (2001) argued that the effects of technical assistance on behaviour were not well understood, but that it was important in assisting landowners in installing conservation practices particularly when conservation practices were complex and unfamiliar. Hagan (1996) found that participants in the Maryland Buffer Incentive Program were younger than nonparticipants.

Profit maximisation theory assumes that the only types of technological innovations that will be adopted are those that increase net returns to the investment (Cary and Wilkinson 1997). Profit maximisation variables used to explain adoption. have included variables related to profit, income and costs. Libby (1985) has argued that soil erosion and runoff from agricultural lands occur because farmers are behaving in a rational, predictable manner. Financial assistance programs (e.g. Federal, State or non-profit) have been established for a variety of conservation practices to compensate producers for removing their land from production. While financial assistance may encourage adoption, this alone is not sufficient to motivate landowner-operators to adopt conservation systems (Napier et al. 2000). Other 
studies have found that conservation practices that are profitable are more likely to be implemented (Nowak and Korsching 1983, Marra and Zering 1996).

Farm structure theory (Buttel and Newby 1980, Napier et al. 1988, 2000) asserts that characteristics of the farm enterprise and farm policies affect adoption behaviour. These authors argue that farm structure factors influence the ability to adopt innovations. Variables related to characteristics of the farm enterprise include: size of the farm operation, farm diversification (i.e. percent of income derived from grain), the percent of farm land that is owned, the number of conservation practices used, and time spent on managing those conservation practices. Adoption was influenced in Washington State by the use of multiple conservation practices (Upadhyay et al. 2003) and individuals willing to participate in a governmentsponsored program to establish conservation practices on their agricultural land were found to spend more time on the management of those practices (Napier et al. 1988). Participants in the Maryland Buffer Incentive Program (BIP) had farms that were generally small (Hagan 1996). In contrast, Norris and Batie (1987) found that early adopters of conservation practices in Virginia had larger farms.

Research into the relationship between farm specialisation and the use of conservation showed mixed results depending on the type of conservation practices examined. However, more specialised and less diverse farms used significantly fewer conservation practices and expended little effort in reducing soil erosion (Ervin and Ervin 1982). Producers deriving more of their income from grain were less willing to participate in government sponsored payment programs to reduce soil erosion (Napier et al. 1988). There is mixed evidence regarding the relationship between farm ownership and the use of conservation practices. Traore et al. (1998) found that land ownership had no significant impact on adoption of conservation practices, but Hagan (1996) reported that the typical BIP participant had much less at stake financially when they converted their riparian lands to RFBs, in part because they owned a greater percentage of land they farmed.

In sum, the empirical and theoretical literature base on adoption is broad and complex. Research has included socio-cultural and diffusion variables, economic variables, and farm structure variables (Nowak 1987, Napier et al. 2000). However, fully understanding adoption behaviour may require the blending of theory (Feder and Umali 1993) and empirical studies. Using variables drawn from these prevailing theories, this study tested two hypotheses: 1) characteristics of RFB adopters differ from those of nonadopters; and 2) predictors of RFB adoption differ between producer and nonproducer respondents.

\section{RESEARCH METHOD}

Two watersheds were selected for the study, namely the Elkhorn River watershed $\left(6354 \mathrm{~km}^{2}\right)$ in north-eastern Nebraska and the Blue River watershed $\left(15,514 \mathrm{~km}^{2}\right)$ in south-eastern Nebraska and Kansas. Each watershed contains five contiguous counties. The two watersheds were chosen because programs aimed at increasing adoption in each watershed were in the planning phase. The Elkhorn River watershed is characterised by hilly land with moderate to steep slopes in the east and plains to the north-west. The Blue River watershed is characterised by plains to the north and hilly land with moderate to steep slopes in the south. Land use in both 
watersheds is a mixture of row crop agriculture and livestock production. Studies by the EPA indicate that both the Blue and Elkhorn River watersheds in Nebraska have impaired surface water quality, primarily a result of nitrogen, phosphorous, pesticides and pathogens (US EPA 1998).

\section{Questionnaire Design}

The questionnaire was developed using theory and personal interviews to identify variables that influence the use of RFBs. Interviews were conducted with Cooperative Extension and natural resource professionals $(n=17)$ and on-farm visits with producers $(n=3)$ to identify variables affecting adoption of RFBs. The draft survey instrument was then submitted to three external reviewers to assess face and content validity. Reviewers were identified and chosen based on their understanding of extension programming, as well as survey instrument design. To assess reliability, the instrument was field tested with south-eastern Nebraska landowners $(n=50)$ identified using plat maps. The final survey instrument incorporated revisions from the field test.

\section{Sample Design and Data Collection}

The population for the survey was drawn from Farm Service Administration (FSA) county mailing lists $(N=16,499)$. Each of the 10 county FSA offices identified individuals receiving a payment for installing a riparian forest buffer under the Natural Resource Conservation Service (NRCS) Conservation Practice 22 (CP 22). The names of individuals receiving a conservation payment for RFBs were removed from the sampling frame (the FSA mailing list) and were treated as adopters for the study. All others were treated as nonadopters. While it was anticipated that individuals may have adopted a riparian forest buffer without participating in a government payment program, checks in the survey and contact with agencies that would be responsible for providing RFB technical assistance did not reveal any additional adopters.

Data were collected using a descriptive survey of respondents in both watersheds. Nonadopters were stratified by county and were proportional to the total population percentage of each county. A census was taken of adopters using a slightly modified questionnaire $(\mathrm{N}=71)$, because of their relatively low number. Using the Dillman Total Design Method (following Dillman 1978), the questionnaire was mailed in February 2003 to a randomly selected stratified sample of nonadopters ( $n=1625$ ). Administration included mailing a cover letter that explained the importance of the research, a copy of the questionnaire, and a stamped return envelope. The mailing procedures included a follow-up reminder postcard sent 10 days after the initial mailing, followed by a second mailing to non-respondents after three weeks. Five hundred and thirteen nonadopters (31.6\%) and 51 adopters (71.8\%) responded to the survey. Of those totals, 309 questionnaires were usable, 261 from nonadopters (16.1\%) and 48 from adopters (67.6\%). Questionnaires were considered unusable if the respondent did not indicate having a stream that qualified for a governmental payment program, their producer status was unknown, or they failed to complete the questionnaire. 


\section{Measurement and Analysis of Variables}

The respondents were classified according to adopter status and producer status. Riparian forest buffer adopter status was identified through county FSA offices. Producer status was determined by asking respondents to indicate whether they were currently farming. The respondents were classified as:

1. Adopters - riparian forest buffer adopters as identified by county FSA offices;

2. Nonadopters - all other names on FSA mailing lists;

3. Producers - respondent indicated that they were currently farming; and

4. Nonproducers - respondent indicated that they were not currently farming.

All statistical analyses were performed using SPSS 11.5 (SPSS Inc. Chicago). The data were measured using close-ended, fill-in, and yes/no questions. Fifteen variables were assessed using either the t-test or chi-square test depending on the type of measurement. t-test statistics were used to test for differences between means for all continuous variables. Chi-square statistics were used to test for differences in frequency of occurrence for all categorical variables. The null hypothesis in each case was that there was no difference in the descriptive characteristics of adopters and nonadopters. The independent variables were measured in the following manner:

1. Age of respondents (years);

2. Absenteeism - respondents residing in a county different to which their name was drawn;

3. Farm size - area farmed, including rented land (ha);

4. Hectares rented to others - area rented to someone else (ha).

5. Number of conservation practices used - out of five key conservation practices (grass waterways, grass filter strips, terraces, field windbreaks, riparian forest buffers);

6. Time spent managing conservation practices - number of days a year spent managing conservation practices using five response categories, ranging from 'less than five days' to 'more than 20 days';

7. Technical assistance - whether technical assistance had been received from a governmental agency in the past five years to install a conservation practice; and

8. Financial assistance - whether financial assistance had been received from a governmental agency in the past five years to install a conservation practice.

Twenty-six attitudinal variables that were previously identified in other studies and from interviews with natural resource professionals as influencing the use of RFBs' were assessed. Reactions were sought to contrasting views regarding management, government payment programs, impacts and financial factors. A seven-point Likert scale was used to assess agreement with the contrasting views, with response categories ranging from 'strongly agree with the view in the left column' to 'strongly agree with the view in the right column'. A 'not sure' category was 
included in the middle of the scale. Positive and negative questions were alternated, which required reversing the weighting values of the responses in some cases for analysis.

Factor analysis was used to assess content validity of the attitudinal variables. The factors were rotated using a Varimax rotation procedure. Box's M statistic was used to test homogeneity of the population variances and covariances across the factors because of the difference in the sample sizes for adopters and nonadopters. The dependent variables were found to have a direct pairing across all levels of the factors, indicating that the assumptions about homogeneity of the populations were tenable. Chronbach's alpha was used to check reliability associated with the variation of the explanatory variables making up each factor. Internal consistency estimates of reliability were computed for each factor. A large coefficient demonstrates a high degree of intercorrelation between the items and that the items can legitimately be combined into a scale score. $A$ value of 0.7 was chosen as the minimum acceptable reliability coefficient.

Logistic regression was used to determine the probability of adoption based on a set of explanatory variables. The adoption of RFBs was used as the response variable. Forward selection was used to identify variables making the greatest contribution to the model. Variables were retained in the model if there was less than $5 \%$ probability of making a type I error. Each model was assessed using the Hosmer and Lemeshow goodness-of-fit test, where a large probability value indicates that the model fits the data well (Hosmer and Lemeshow 1989). Variables entering the models can be found in Table 1 .

\section{FACTOR ANALYSIS RESULTS, RESPONDENT CHARACTERISTICS, AND LOGISTIC REGRESSION EQUATIONS}

\section{Data Reduction Using Factor Analysis}

Attitudinal variables used in developing the factor scales are listed in Table 2. Factors, their contribution to explained variation and internal consistency estimates of reliability of each factor (Cronbach's alpha) are presented in Table 3. In the analysis of 26 attitudinal variables affecting the use of RFBs, seven interpretable factors accounted for $59.8 \%$ of the explained variation. One factor, perceptions about the impacts of RFBs (23.8\%), contributed about two-fifths of the variance explained by the seven factors. Because the reliability scores of Factors 5 to 7 did not meet the minimum validity requirements of Cronbach's alpha, they were not included in the logistic regression analysis. 
Table 1. Variables included in riparian forest buffer models

\begin{tabular}{|c|c|c|}
\hline Variable & Variable description & Measure \\
\hline \multicolumn{3}{|l|}{ Dependent } \\
\hline Producers & $0=$ adopter producers $1=$ nonadopter producers & 0,1 \\
\hline Nonproducers & $0=$ adopter nonproducers $1=$ nonadopter nonproducers & 0,1 \\
\hline \multicolumn{3}{|l|}{ Independent } \\
\hline Rent & Total hectares rented out to producers by nonproducers & Hectares $^{1}$ \\
\hline Farm & Total acres farmed by producers & Hectares \\
\hline Own & $\begin{array}{l}\text { Percentage of land in production that is owned by } \\
\text { producers }\end{array}$ & Percent \\
\hline Grain & $\begin{array}{l}\text { Percentage of gross farm income derived from corn, } \\
\text { soybeans, wheat and milo in } 2001\end{array}$ & Percent \\
\hline Absenteeism & $\begin{array}{l}\text { Respondent lives in the county from which their name was } \\
\text { drawn }\end{array}$ & $0,1^{2}$ \\
\hline Age & Respondent age in years & Years \\
\hline Technical assistance & $\begin{array}{l}\text { Receipt of technical assistance in the last five years to } \\
\text { install a conservation practice }\end{array}$ & $0,1^{2}$ \\
\hline Financial assistance & $\begin{array}{l}\text { Receipt of financial assistance in the last five years to } \\
\text { install a conservation practice }\end{array}$ & $0,1^{2}$ \\
\hline Conservation & Number of vegetative conservation practices used & Number \\
\hline Management & Time spent managing conservation practices & $0,1,2,3,4^{3}$ \\
\hline RFB impact scale & Perceptions about the impacts of RFBs & 5 to $35^{4}$ \\
\hline $\begin{array}{l}\text { RFB program } \\
\text { payment scale }\end{array}$ & Perceptions about RFB governmental payment programs & 5 to $35^{4}$ \\
\hline RFB attribute scale & Perceptions about the attributes of RFBs & 4 to $28^{4}$ \\
\hline $\begin{array}{l}\text { RFB program } \\
\text { resistance scale }\end{array}$ & $\begin{array}{l}\text { Perceptions about participating in a government program to } \\
\text { establish RFBs }\end{array}$ & 2 to $14^{4}$ \\
\hline
\end{tabular}

${ }^{1} 1$ acre $=0.405$ ha.

${ }^{2}$ Yes coded $0 ;$ No coded 1.

${ }^{3} 0-5$ days coded $0 ; 5-10$ days coded $1 ; 11-15$ days coded $2 ; 16-20$ days coded 3 ; more than 20 days coded 4.

${ }^{4}$ Range of the minimum to maximum score for each scale. 
Table 2. Mean attitudes toward using riparian forest buffers $(n=309)$

\begin{tabular}{|c|c|c|c|c|c|}
\hline \multirow[t]{2}{*}{ Attitude statement } & \multicolumn{2}{|c|}{ Adopters } & \multicolumn{2}{|c|}{ Nonadopters } & \multirow[t]{2}{*}{ Comment } \\
\hline & Producer & Nonproducer & Producer & Nonproducer & \\
\hline $\begin{array}{l}\text { Establishment of } \\
\text { trees in a buffer is } \\
\text { not difficult. }\end{array}$ & $5.30 \pm 0.42$ & $5.24 \pm 0.32$ & $4.48 \pm 0.13$ & $4.08 \pm 0.15$ & $\begin{array}{l}\text { Establishment of trees } \\
\text { in a buffer is difficult. }\end{array}$ \\
\hline $\begin{array}{l}\text { Forest buffers are } \\
\text { compatible with } \\
\text { current farming } \\
\text { practices. }\end{array}$ & $3.30 \pm 0.44$ & $2.84 \pm 0.30$ & $3.94 \pm 0.13$ & $3.70 \pm 0.15$ & $\begin{array}{l}\text { Forest buffers are not } \\
\text { compatible with } \\
\text { current farming } \\
\text { practices. }\end{array}$ \\
\hline $\begin{array}{l}\text { Forest buffers do } \\
\text { not require too } \\
\text { much maintenance. }\end{array}$ & $4.05 \pm 0.41$ & $4.88 \pm 0.36$ & $4.17 \pm 0.13$ & $3.78 \pm 0.12$ & $\begin{array}{l}\text { Forest buffers do } \\
\text { require too much } \\
\text { maintenance. }\end{array}$ \\
\hline $\begin{array}{l}\text { The sign-up } \\
\text { process is a hassle. }\end{array}$ & $5.50 \pm 0.33$ & $4.50 \pm 0.35$ & $3.66 \pm 0.13$ & $3.59 \pm 0.12$ & $\begin{array}{l}\text { The sign-up process is } \\
\text { not a hassle. }\end{array}$ \\
\hline $\begin{array}{l}\text { I am less likely to } \\
\text { establish a forest } \\
\text { buffer due to } \\
\text { government } \\
\text { regulation. }\end{array}$ & $5.15 \pm 0.33$ & $4.96 \pm 0.30$ & $3.75 \pm 0.13$ & $3.78 \pm 0.14$ & $\begin{array}{l}\text { Government regulation } \\
\text { does not affect my } \\
\text { decision to install } \\
\text { forest buffers. }\end{array}$ \\
\hline $\begin{array}{l}\text { The forest buffer } \\
\text { program } \\
\text { qualification } \\
\text { requirements are } \\
\text { inflexible. }\end{array}$ & $4.60 \pm 0.29$ & $4.00 \pm 0.32$ & $3.84 \pm 0.09$ & $3.88 \pm 0.80$ & $\begin{array}{l}\text { The forest buffer } \\
\text { program qualification } \\
\text { requirements are } \\
\text { flexible. }\end{array}$ \\
\hline $\begin{array}{l}\text { The forest buffer } \\
\text { program financial } \\
\text { incentives are } \\
\text { adequate. }\end{array}$ & $3.90 \pm 0.50$ & $3.67 \pm 0.37$ & $4.52 \pm 0.12$ & $4.33 \pm 0.10$ & $\begin{array}{l}\text { The forest buffer } \\
\text { program financial } \\
\text { incentives are not } \\
\text { adequate. }\end{array}$ \\
\hline $\begin{array}{l}\text { Efforts to sign up } \\
\text { for forest buffer } \\
\text { programs are worth } \\
\text { the program } \\
\text { payment. }\end{array}$ & $2.90 \pm 0.33$ & $2.83 \pm 0.35$ & $4.29 \pm 0.10$ & $4.07 \pm 0.10$ & $\begin{array}{l}\text { Efforts to sign up for } \\
\text { forest buffer programs } \\
\text { are not worth the } \\
\text { program payment. }\end{array}$ \\
\hline $\begin{array}{l}\text { The forest buffer } \\
\text { program design } \\
\text { requirements are } \\
\text { flexible. }\end{array}$ & $2,90 \pm 0.25$ & $3.04 \pm 0.31$ & $4.12 \pm 0.08$ & $4.00 \pm 0.06$ & $\begin{array}{l}\text { The forest buffer } \\
\text { program design } \\
\text { requircments are } \\
\text { inflexible. }\end{array}$ \\
\hline $\begin{array}{l}\text { Water is trapped } \\
\text { where the edge of } \\
\text { the field meets the } \\
\text { forest buffer. }\end{array}$ & $4.48 \pm 0.45$ & $5.00 \pm 0.30$ & $3.96 \pm 0.14$ & $4.06 \pm 0.12$ & $\begin{array}{l}\text { Water moves from the } \\
\text { field across the forest } \\
\text { buffer. }\end{array}$ \\
\hline $\begin{array}{l}\text { Having a forest } \\
\text { buffer only on my } \\
\text { farm does not } \\
\text { improve water } \\
\text { quality in the } \\
\text { watershed. }\end{array}$ & $5.80 \pm 0.28$ & $5.04 \pm 0.30$ & $4.81 \pm 0.11$ & $4.84 \pm 0.12$ & $\begin{array}{l}\text { Having a forest buffer } \\
\text { only on my farm does } \\
\text { improve watcr quality } \\
\text { in the watershed. }\end{array}$ \\
\hline $\begin{array}{l}\text { Trees and shrubs } \\
\text { provide bank } \\
\text { stabilisation. }\end{array}$ & $1.55 \pm 0.15$ & $2.00 \pm 0.23$ & $2.43 \pm 0.12$ & $2.66 \pm 0.15$ & $\begin{array}{l}\text { Trees and shrubs do } \\
\text { not provide bank } \\
\text { stabilisation. }\end{array}$ \\
\hline $\begin{array}{l}\text { Having trees in a } \\
\text { forest buffer does } \\
\text { not complicate field } \\
\text { operations. }\end{array}$ & $2.80 \pm 0.45$ & $2.71=0.35$ & $4.33 \pm 0.14$ & $3.96 \pm 0.15$ & $\begin{array}{l}\text { Having trees in a forest } \\
\text { buffer complicates } \\
\text { field operations. }\end{array}$ \\
\hline
\end{tabular}

Responses weighted 1 to 7, 'strongly agree with item in left column' coded 1 and 'strongly agree with item in right column' coded 7 . Undecided coded 4. 
Table 2, (Cont.)

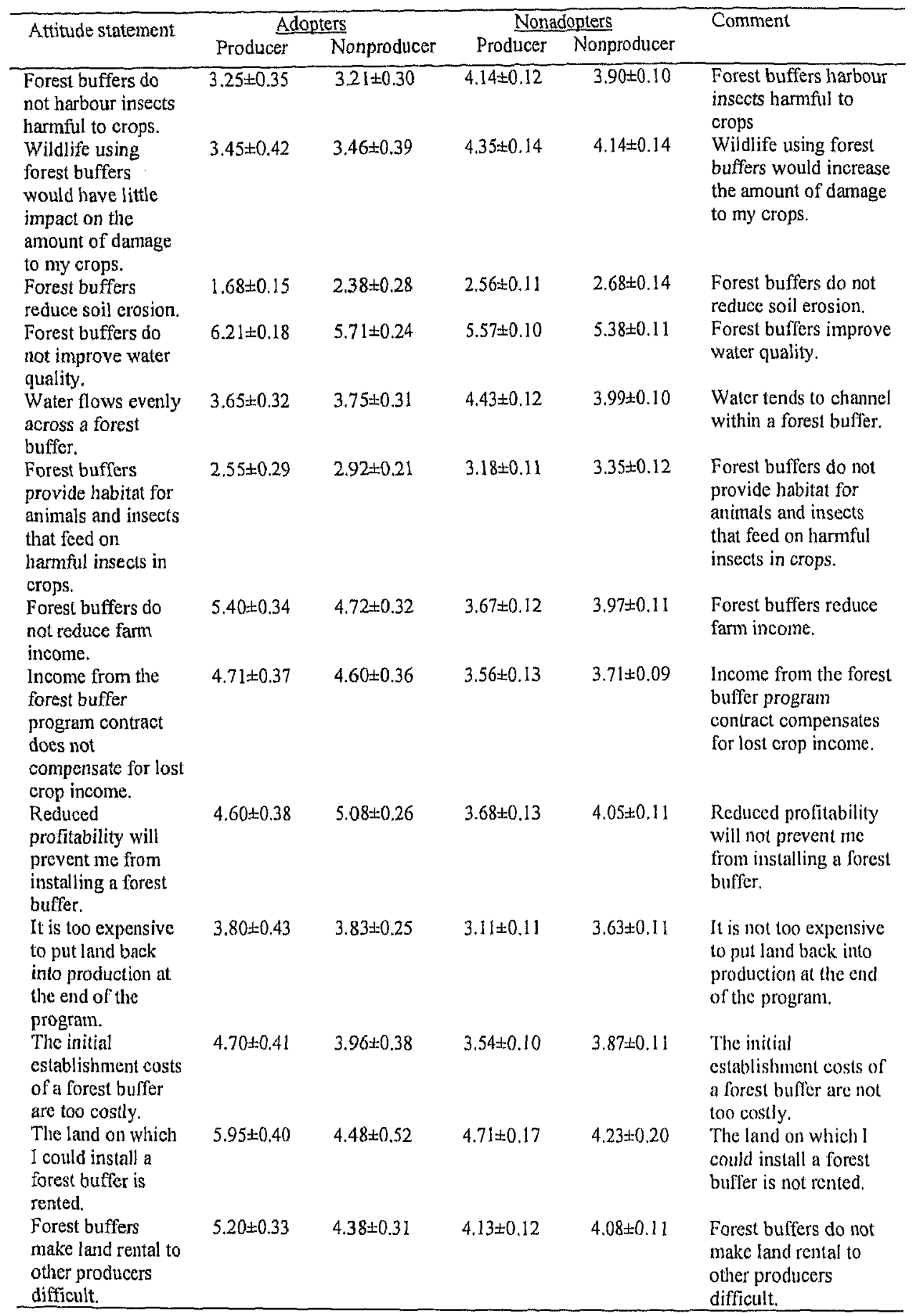

Responses weighted 1 to 7, 'strongly agree with item in left column' coded 1 and 'strongly agree with item in right column' coded 7 . Undecided coded 4. 


\section{Characteristics of Adopters, Nonadopters, Producers and Nonproducers}

Adopters and nonadopters were significantly different on several of the categorical and continuous variables (Table 4). The population was about evenly split between producers $(n=167)$ and nonproducers $(n=142)$. The findings show that among the adopter respondents, nonproducers $(n=25)$ are as likely to adopt RFBs as producers $(n=23)$. Adopters were more likely to have received technical and financial assistance than nonadopters. Adopters spent more time on the management of their conservation practices and were more likely to use key conservation practices than nonadopters. Adopter perceptions were significantly different to nonadopters with regard to each of the top four factors. There are no significant differences in age or absenteeism between adopters and nonadopters.

Several characteristic parameters assessed only for adopter and nonadopter status groups, both producers and nonproducers, were significantly different. Adopter producers had smaller farms, owned a greater percentage of the land they farmed, and derived less of their income from grain production. There was no significant difference in the amount of land rented to others by nonproducer adopters and nonadopters.

Table 3. Rotated factor matrix for scaled riparian forest buffer attitude items

\begin{tabular}{|c|c|c|c|c|c|c|c|c|c|}
\hline \multirow[t]{2}{*}{ Scaled items ${ }^{1}$} & \multicolumn{7}{|c|}{ Factor loading } & \multirow{2}{*}{$\begin{array}{c}\text { Explained } \\
\text { variance } \\
(\%)\end{array}$} & \multirow{2}{*}{$\begin{array}{l}\text { Cronbach's } \\
\text { alpha }\end{array}$} \\
\hline & 1 & 2 & 3 & 4 & 5 & 6 & 7 & & \\
\hline RFB impact sce & & & & & & & & 23.84 & 0.79 \\
\hline $\begin{array}{l}\text { Forest buffers } \\
\text { do not } \\
\text { improve } \\
\text { water quality. }\end{array}$ & $0.827^{2}$ & 0.010 & 0.157 & 0.137 & -0.068 & -0.095 & 0.119 & & \\
\hline $\begin{array}{l}\text { Forest buffers } \\
\text { do not reduce } \\
\text { soil erosion. }\end{array}$ & 0.802 & -0.005 & 0.237 & 0.009 & 0.074 & $-0,033$ & -0.035 & & \\
\hline $\begin{array}{l}\text { Trees and } \\
\text { shrubs do not } \\
\text { provide bank } \\
\text { stabilisation. }\end{array}$ & 0.592 & 0.040 & -0.002 & -0.132 & 0.315 & 0.004 & 0.097 & & \\
\hline $\begin{array}{l}\text { Forest buffers } \\
\text { do nol } \\
\text { provide } \\
\text { habitat for } \\
\text { animals or } \\
\text { insects that } \\
\text { feed on } \\
\text { harmful } \\
\text { insects in } \\
\text { crops. }\end{array}$ & 0.577 & 0.158 & -0.055 & 0.217 & 0.292 & 0.128 & -0.150 & & \\
\hline $\begin{array}{l}\text { Having a } \\
\text { forest buffer } \\
\text { only on my } \\
\text { farm does not } \\
\text { improve } \\
\text { water quality } \\
\text { in the } \\
\text { watershed. }\end{array}$ & 0.475 & 0.135 & 0.378 & 0.098 & 0.039 & 0.075 & 0.003 & & \\
\hline
\end{tabular}


Table 3. (Cont.)

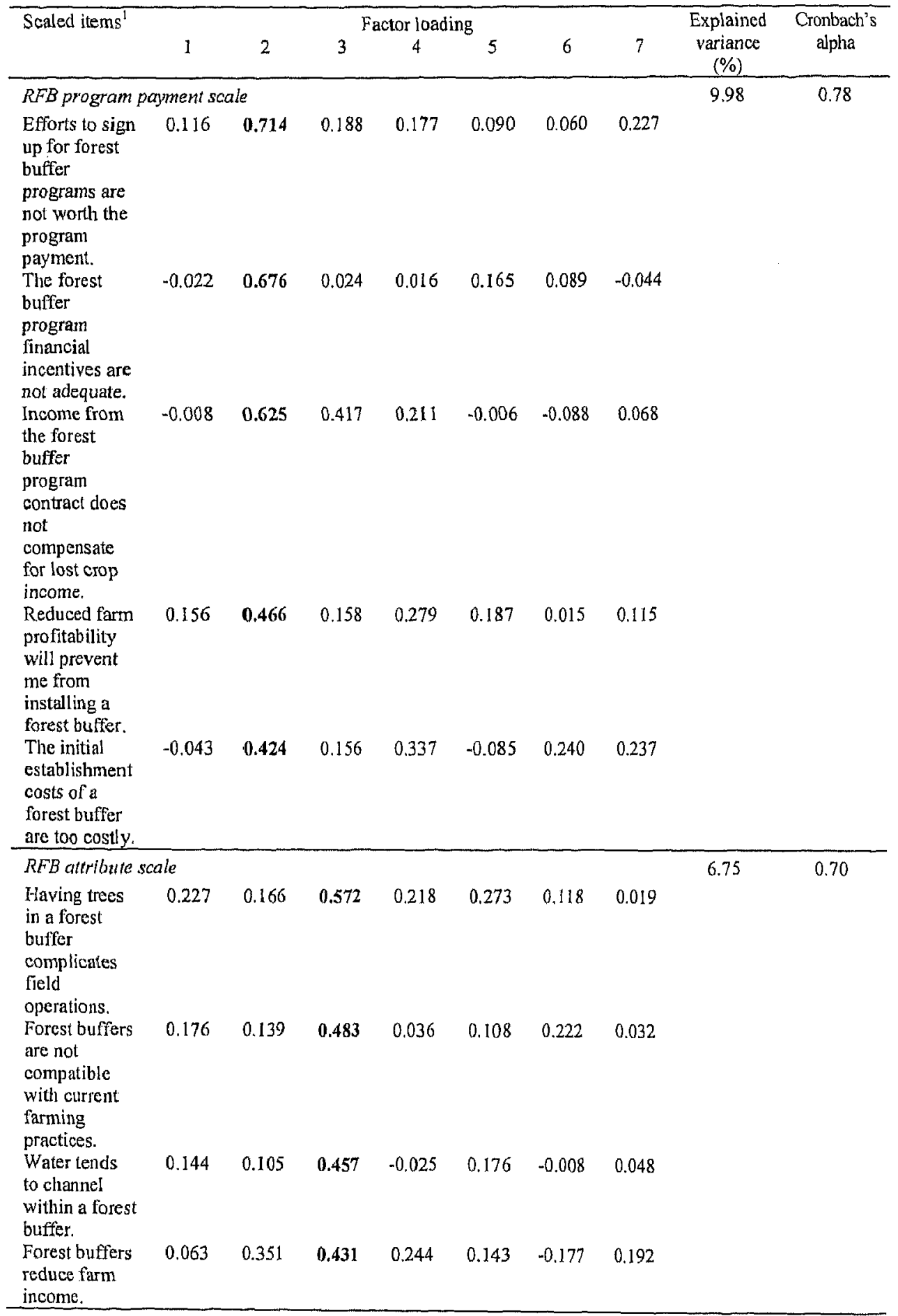


Table 3. (Cont.)

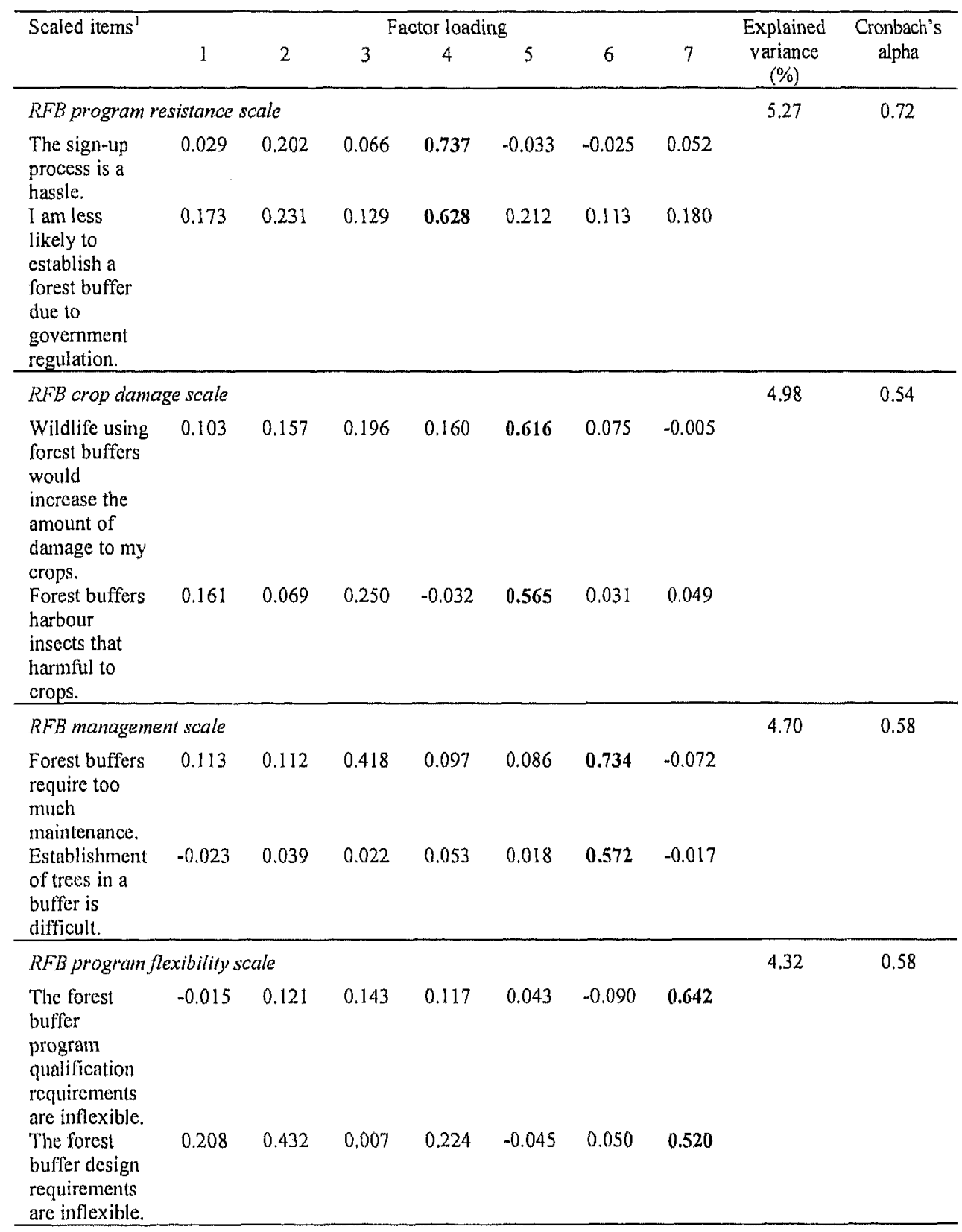

${ }^{1}$ Scaled items have been recoded so that all variable weighting values are in the same direction.

${ }^{2}$ Boldface indicates highest factor loadings. 
Table 4. Descriptive statistics for all variables

\begin{tabular}{|c|c|c|c|c|c|c|c|c|c|}
\hline $\begin{array}{l}\text { Categorical } \\
\text { variables }\end{array}$ & Measure & $\mathrm{n}$ & $\%$ of & $\%$ of 1 & $\%$ of 2 & $\%$ of 3 & $\%$ of 4 & $\begin{array}{l}\operatorname{Pr}> \\
X^{2} \\
\end{array}$ & Direction' \\
\hline Producers ${ }^{2}$ & $0,1^{3}$ & 167 & 13.8 & 86.2 & - & - & - & $*$ & - \\
\hline Nonproducers ${ }^{2}$ & $0,1^{3}$ & 142 & 17.6 & 82.4 & - & - & $=$ & * & - \\
\hline \multirow{3}{*}{$\begin{array}{l}\text { Absenteeism } \\
\text { Technical } \\
\text { assistance } \\
\text { Financial } \\
\text { assistance }\end{array}$} & $0,1^{4}$ & 309 & 68.3 & 31.7 & - & - & - & 0.04 & - \\
\hline & $0,1^{5}$ & 309 & 43.0 & 57.0 & - & - & - & 0.00 & + \\
\hline & $0,1^{5}$ & 309 & 44.0 & 56.0 & - & - & - & 0.00 & + \\
\hline Management & $0,1,2,3,4^{6}$ & 309 & 48.5 & 29.1 & 8.7 & 6.2 & 7.4 & 0.07 & + \\
\hline $\begin{array}{l}\text { Continuous } \\
\text { variables }\end{array}$ & Measure & $\mathrm{n}$ & Mean & S.E. & $P_{r}>T$ & Direction & & & \\
\hline Rent & Hectares? & 142 & 131 & 23 & 0.44 & - & & & \\
\hline Farm & Hectares & 167 & 356 & 25 & 0.02 & - & & & \\
\hline Own & Percent & 167 & 54.8 & 0.0 & 0.03 & + & & & \\
\hline Grain & Percent & 167 & 72.2 & 2.1 & 0.00 & - & & & \\
\hline Age & Years & 309 & 55 & 0.8 & 0.18 & - & & & \\
\hline Concervation & Number & 309 & 1.8 & 0.1 & 0.01 & + & & & \\
\hline & 5 to $35^{8}$ & 309 & 26.4 & 0.3 & 0.00 & + & & & \\
\hline $\begin{array}{l}\text { payment seale } \\
\text { RFB attribute }\end{array}$ & 5 to $35^{8}$ & 309 & 19.4 & 0.3 & 0.00 & + & & & \\
\hline $\begin{array}{l}\text { scale } \\
\text { RFB program } \\
\text { resistance }\end{array}$ & 4 to $28^{8}$ & 309 & 16.2 & 0.3 & 0.00 & + & & & \\
\hline scale & 2 to $14^{8}$ & 309 & 7.8 & 0.2 & 0.00 & + & & & \\
\hline
\end{tabular}

'Direction in which adopters differ from nonadopters. For categorical variables, it is a comparison of the percentages, which were equally weighted for comparison. For continuous variables, it is the comparison of means.

${ }^{2}$ Dependent variables.

${ }^{3}$ Adopter coded 0 ; nonadopter coded 1 .

${ }^{4}$ In county residence coded 0 ; out of county residence coded 1.

${ }^{5}$ Received assistance coded 0 ; did not receive assistance coded 1 .

${ }^{6} 0-5$ days coded $0 ; 5-10$ days coded $1 ; 11-15$ days coded $2 ; 16-20$ days coded $3 ;$ more than 20 days coded 4 .

${ }^{7} \mathrm{I}$ acre $=0.405$ ha.

${ }^{8}$ Range of the minimum to maximum score for each scale.

\section{Logistic Regression Models for Predicting Factors Affecting Adoption}

The logistic regression models used for predicting factors affecting adoption of RFBs by producers and nonproducers were significant. For the model predicting factors affecting adoption of RFBs by producers, there was insufficient evidence to reject the model for lack of fit $(p=0.406)$. For the model predicting factors affecting the adoption of RFBs by nonproducers, there was insufficient evidence to reject the model for lack of fit $(\mathrm{p}=0.940)$. 
Three variables were found to be significant for the producer model: 1) perceptions about RFB attributes; 2) receiving financial assistance; and 3) perceptions about participating in a government payment program to establish RFBs (Table 5). Using these three predictors, the model correctly predicts group membership (i.e. adopter or nonadopter producers) for $90.4 \%$ of the respondents. Receiving financial assistance was positively related to adoption.

Three variables were found to be significant for the nonproducer model: 1) receiving technical assistance; 2) the perceptions about RFB governmental payment programs; and 3) age. Using these three predictors, the model correctly predicts group membership (i.e. adopter or nonadopter nonproducers) for $85.9 \%$ of the respondents. Technical assistance and age were positively related to adoption.

Table 5. Significant explanatory variables entering the logistic regression adoption models

\begin{tabular}{|c|c|c|c|c|c|c|}
\hline \multirow[t]{2}{*}{ Group and variables } & \multirow{2}{*}{$\begin{array}{l}\text { Parameter } \\
\text { estimate }\end{array}$} & \multirow[t]{2}{*}{ Significance } & \multirow[t]{2}{*}{ Odds ratio } & \multicolumn{3}{|c|}{ Percent correct predictions } \\
\hline & & & & Adopters & Nonadopters & Total \\
\hline Producers & & & & 34.8 & 95.8 & 90.4 \\
\hline Inlercept & 4.593 & 0.020 & & & & \\
\hline RFB attribute scale & -0.218 & 0.004 & 0.804 & & & \\
\hline $\begin{array}{l}\text { Financial assistance } \\
\text { RFB program resistance }\end{array}$ & 2.914 & 0.007 & 18.426 & & & \\
\hline Nonproducers & & & & 52.0 & 93.2 & 85.9 \\
\hline Intercept & 1.125 & 0.642 & & & & \\
\hline $\begin{array}{l}\text { Technical assistance } \\
\text { RFB program payment }\end{array}$ & 3.002 & 0.000 & 20.131 & & & \\
\hline scale & -0.231 & 0.002 & 0.794 & & & \\
\hline Age & 0.062 & 0.015 & 1.064 & & & \\
\hline
\end{tabular}

\section{DISCUSSION}

Goverumental agencies have developed a wide array of technical and financial assistance programs to help landowners install riparian forest buffers. However, adoption of riparian forest buffers has been limited in Nebraska. Less than $1 \%$ of the total population has installed a riparian forest buffer in the two study watersheds. To improve water quality at the local, regional and national levels, policy-makers, program managers, and extension professionals must understand the characteristics and perceptions that distinguish adopters from nonadopters and understand the differences between producer and nonproducer needs. Programs should be designed and implemented to remove the barriers to adoption within the context of a changing agricultural structure. Given the current impaired water quality in the two Nebraska watersheds studied, it is clear that the level of adoption of RFBs needs to be increased.

The results of this study indicate that definitions of who is an adopter clearly need to be broadened to address a diverse and changing population of future adopters. In previous studies, adopters have been defined as producers without assessing whether nonproducers were actually making conservation decisions in the study areas. 
Whether to adopt RFBs presents a complex decision, with many factors at work influencing the respondent's decision to install a RFB. Seven primary factors explain $60 \%$ of the variation in attitudes toward RFBs. The first and second factors, the RFB impact scale and RFB program payment scale, account for two-thirds of the total variability of the seven factors. This is a clear indication that there are large differences in knowledge and understanding about the ecological and biological functions of RFBs, as well as in the understanding about RFB program payments. In order to consider the adoption of RFBs, understanding the function and related environmental services provided by RFBs is critical, and nonadopters must be provided with economic information that allows them to compare RFB program payments with their current practices.

Adopters and nonadopters perceive factors affecting use of RFBs differently, indicating that this a logical starting point from which to begin removing the barriers to adoption. Results from this study support previous findings that adopters tend to use more conservation practices (reported by Upadhyay et al. 2003) and spend more time on the management of those practices (Napier et al. 1988). Farm size findings are consistent with Hagan (1996) but are in contrast with the finding that adopters of conservation practices are more likely to have larger farms, reported by Norris and Batie (1987) and Upadhyay et al. (2003). Results related to land ownership and grain production were also consistent with previous research findings that RFB adopters have less at stake financially (Hagan 1996) and adopters of conservation practices in general are less reliant on income from grain (Napier et al. 1988). These findings support the first hypothesis that the characteristics of RFB adopters and nonadopters differ.

There is also a different set of significant explanatory variables for producers and nonproducers, indicating a difference in their perceptions. The findings from the logistic regression models support the second hypothesis that different sets of predictor variables explain differences in adoption by producers and nonproducers. While the literature base suggests uncertainty as to the importance of financial and technical assistance, findings from this study suggest that producers who have received financial cost share assistance to install a conservation practice in the last five years are 18 times as likely to be adopters of RFBs. Similarly, nonproducers who have received technical assistance, which could be broadly interpreted from personal assistance to educational programming that provides technical information, are 20 times as likely to have adopted RFBs. Of all the groups, nonadopter nomproducers tend to be the least certain about financial incentives or to have received technical information. These knowledge gaps may indicate that current RFB promotion and educational programs may be missing nonproducers as decision-makers. Not recognising these other adopters who participate in decisionmaking may result in inadequate program targeting and considerably lower adoption rates.

Blending various theoretical constructs to guide the investigation was useful in helping to understand differences in the groups' perceptions regarding the use of RFBs. For example, variables related to profit emerge in two of the factors, appearing to be a mixture of income and diffusion variables. However, profit maximisation does not appear to be an interpretable predictor of RFB adoption for several reasons. Adopters believe that RFBs do not increase short-term profit and that RFBs reduce farm income. Nevertheless, reduced profitability has not prevented 
them from installing a RFB. They also agreed that income from the RFB program contract compensated for installation of the buffer and that the RFB program financial incentives were adequate. In each instance, these attitudes are reversed for nonadopters. Additionally, the amount of land removed from production to install a RFB is small relative to total farm size, and it appears that adopter experience with the system provides them with a better understanding of the economics. Conversely, nonproducers may simply not be aware of the actual payment structure or may not have made meaningful economic evaluations of the system.

Social-psychological variables appear in each of the logistic regression equations. This is a strong indicator that nonadopters are influenced by availability of RFB information, and that their perceptions about RFBs are inhibiting adoption. Nonadopters tended to be undecided about RFBs and they were also less likely to have received technical or financial assistance to install a conservation practice. Variables related to farm structure emerge in perceptions about the government programs. This is consistent with the theory that agricultural policies in general provide numerous incentives and disincentives for adoption of conservation practices.

\section{CONCLUDING COMMENTS}

The lack of basic RFB knowledge appears to be a major barrier to adoption. Adopters were more informed than nonadopters about RFBs and more willing to accept government payments to install them. They also received more technical and financial assistance. Thus, it appears that there are several key respondent characteristics that can be used to identify potential adopters. Producers who are less specialised, farming less than 400 ha, live near the site where a RFB could be established, and are willing to participate in government payment programs, are more likely to adopt RFBs. Similarly, nonproducers who are younger, live near the site where a RFB could be established, and are not negatively influenced by government payment programs are more likely to adopt RFBs.

In summary, there were several key findings from this study. First, by understanding group membership, the characteristics of those groups, and the explanatory variables affecting the use of RFBs, it is possible to broadly predict who will adopt RFBs and who will not. Second, it is clear that the provision of technical and financial assistance has an impact on the adoption of RFBs. Third, the findings of this study expose major opportunities for more targeted extension and education programming. Experience in Nebraska reveals that in conducting RFB training workshops, the majority of audience participants are producers. Yet the findings from this study indicate that nonproducers are as likely as producers to be adopters. Thus, extension and education programs aimed at increasing the number of riparian forest buffer installations should focus on countering negative attitudes about RFB attributes and government payment programs. This should include targeting potential adopters from the various demographic groups that reflect the changing structure of agriculture. 


\section{REFERENCES}

Buttel, F.H. and Newby, H. (1980), The Rural Sociology of Advanced Societies, Allenheld Osman, Montclair, New Jersey.

Cary, J.W. and Wilkinson, R,L. (1997), 'Perceived profitability and farmers' conservation behavior', Journal of Agricultural Economics, 48(1): 13-21.

Colletti, J., Schulz, D., Faltonson, R. and Isenhart, T. (1995), 'Creating a buffer', lowa Conservationist, July/August: $37-41$,

Constance, D.H., Rikoon, J.S. and Heffernan, W.D. (1995), 'Separation of ownership and environmental decision-making on rented farmland', in Clean Water - Clean Environment $2 I^{s /}$ Century, Volume III: Practices, Systems and Adoption, Proceedings of a conference held 5-8 March 1995, American Society of Agricultural Engineers, Kansas City, MO, pp. $65-68$,

Dillman, D.A. (1978), Mail and Telephone Surveys: The Total Design Method, Wiley, New York.

Ervin, C.A. and Ervin, D.E. (1982), 'Factors affecting the use of soil conservation practices: hypotheses, evidence, and policy implications', Land Economics, 58(3): 277-292.

Feder, G. and Umali, D.L. (1993), 'The adoption of agricultural innovations: a review', Technological Forecasting and Social Change, 43: 215-239.

Hagan, P.T. (1996), 'Evaluating determinants of participation in voluntary riparian buffer programs: a case study of Maryland's Buffer Incentive Program,' in Undersianding the Science Behind Riparian Forest Buffers: Effects on Water Quality, Virginia Cooperative Extension, Publication 420-151, Blacksburg, VA.

Hosmer, D.W. and Lemeshow, S. (1989), Applied Logistic Regression, Wiley, New York.

Klapproth, J.C. and Johnson, J.E. (2001), Understanding the Science Behind Riparian Forest Buffers: Effects on Water Quality, Virginia Cooperative Extension, Publication 420-151, Blacksburg, VA.

Kraft, S.E., Lant, C.L. and Gillman, K.R. (1996), 'WQIP: An assessment of its chance for acceptance by farmers', Journal of Soil and Water Conservation, 51(6): 494-498.

Lasley, P. and Kettner, K. (1990), 'Iowa farm and rural life poll 1990 summary', Iowa State University Extension, Ames.

Lee, K.H., Isenhart, T.M. and Schultz, R.C. (2003), 'Sediment and nutrient removal in an established multi-species riparian buffer', Journal of Soil and Water Conservation, 58(1): $1-8$.

Libby, L.W. (1985), 'Paying the nonpoint pollution control bill', Journal of Soil and Water Conservation, 40(1): 33-36.

Lichtenberg, E. and Lessley, B.V. (1992), 'Water quality, cost-sharing, and technical assistance: perceptions of Maryland farmers', Journal of Soil and Water Conservation, 47(3): 260-264.

Lowrance, R., McIntyre, S. and Lance, J.C. (1988), 'Erosion and deposition in a coastal plain watershed measured using CS-137', Journal of Soil and Water Conservation, 43(2): 195 198.

Lowrance, R., Dabney, S. and Schultz, R. (2002), 'Improving water and soil quality with conservation buffers', Journal of Soil and Water Conservation, 57(2): 37A-43A.

Marra, M. and Zering, K. (1996), Finding the best of the best in water quality BMPs: the Economist's viewpoint, North Carolina State University Department of Agricultural and Resource Economics, Publication AREP96-10.

Napier, T.L., Thranen, C.S. and Camboni, S.M. (1988), 'Willingness of land operators to participate in government sponsored soil erosion control programs', Journal of Rural Studies, 4(4): 339-347.

Napier, T.L., Tucker, M. and McCarter, S. (2000), 'Adoption of conservation production systems in three Midwest watersheds', Joumal of Soil and Water Conservation, 55(2): 123-134.

Nebraska Department of Environmental Quality (2002), 2002 Nebraska Water Quality Report, Department of Environmental Quality, Water Quality Division, Lincoln.

Norris, P.E. and Batie, S.S. (1987), 'Virginia farmers' soil conservation decisions: an application of tobit analysis', Southern Journal of Agricultural Economics, 19(1): 79-90.

Nowak, P.J. (1987), 'The adoption of agricultural conservation technologies: Economic and diffusion explanations', Rural Sociology, 52(2): 208-220. 
Nowak, P.J. and Korsching, P.F. (1983), 'Social and institutional factors affecting the adoption and maintenance of agricultural BMPs', in F.W. Schaller and G.W. Bailey (eds), Agricultural Management and Water Quality, pp. 349-373, Iowa State University Press, Ames.

Nunnally, J. (1978), Pyschometric Theory, McGraw-Hill, New York.

Osborne, L.L. and Kovacic, D.A. (1993), 'Riparian vegetated buffer strips in water-quality restoration and stream management', Freshwater Biology, 29: 243-258.

Palone, R.S. and Todd, A.H. (eds) (1997), Chesapeake Bay Riparian Handbook: A Guide for Establishing and MaintainingRiparian Forest Buffers, USDA Forest Service, NA-TP-0297, Radnor, PA.

Rogers, E.M. (1983), Diffusion of Innovations, The Free Press, New York.

Schultz, R.C., Colletti, J.P., Isenhart, T.M., Marquez, C.O., Simpkins, W.W. and Ball, C.J. (2000), 'Riparian Forest Buffer Practices', in H.E. Garrett, W.J. Rietveld and R.F. Fisher (eds), North American Agroforestry: An Integrated Science and Practice, American Society of Agronomy, Madison, pp. 189-281.

Schultz, R.C., Isenhart, T.M., Simpkins, W.W. and Colletti, J.P. (2004), 'Riparian forest buffers in agroecosystems - lessons learned from the Bear Creek Watershed, Central Iowa, USA', Agroforestry Systems, 61: 35-50.

Steiner, F.R. (1990), Soil Conservation in the United States: Policy and Planning, Johns Hopkins University Press, Baltimore.

Traore, N., Landry, R. and Amara, N. (1998), 'On-farm adoption of conservation practices: The role of the farm and farmer characteristics, perceptions, and health hazards', Land Economics, 74(1): 114-127.

USDA (United States Department of Agriculture), National Agriculture Statistics Service (2002), 2002 Census of Agriculture - State Data, www.nass.usda.gov/census02, accessed March 2004.

USDA (United States Department of Agriculture) (2003), Agricultural Resources and Environmental Indicators, USDA Economic Service Agricultural Handbook No. AH722, Washington, DC.

U.S. EPA (United States Environmental Protection Agency) (1998), '1998 Section 303(d) List Fact Sheet for Nebraska', www.oaspub.epa.gov/waters/state_rept.control?p_state $=$ NE, 1998, accessed May 2000.

Upadhyay, B.M., Young, D.L., Wang, H.H. and Wandschneider, P. (2003), 'How do farmers who adopt multiple conservation practices differ from their neighbors?', American Journal of Alternative Agriculture, 18(1): 27-36.

Van Es, J.C. (1983), 'The adoption/diffusion tradition applied to resource conservation: Inappropriate use of existing knowledge', The Rural Sociologist, 3(2): 76-82. 